DR STEPHEN HARRINGTON is a senior lecturer in Journalism, Media and Communication at Queensland University of Technology.

\title{
Help at hand to navigate legal minefields
}

The Journalist's Guide to Media Law, 4th Edition, Mark Pearson and Mark Polden. Sydney: Allen \& Unwin, 2011, 480 pp. ISBN 9781742370385

Blogging and Tweeting Without Getting Sued: A Global Guide to the Law for Anyone Writing Online, Mark Pearson. Sydney: Allen \& Unwin, 2012, 222 pp. ISBN 9781742378770

$\mathrm{O}$ VER recent years in Australia we have seen a number of big stories emerge which highlight the difficult legal positions in which journalists too often find themselves. One of the biggest was Gina Rinehart's attempts in Western Australia to have journalists reveal their sources for stories which were published regarding the legal battles she had been fighting against her own children. Another involved the 2009 counter-terrorism operations

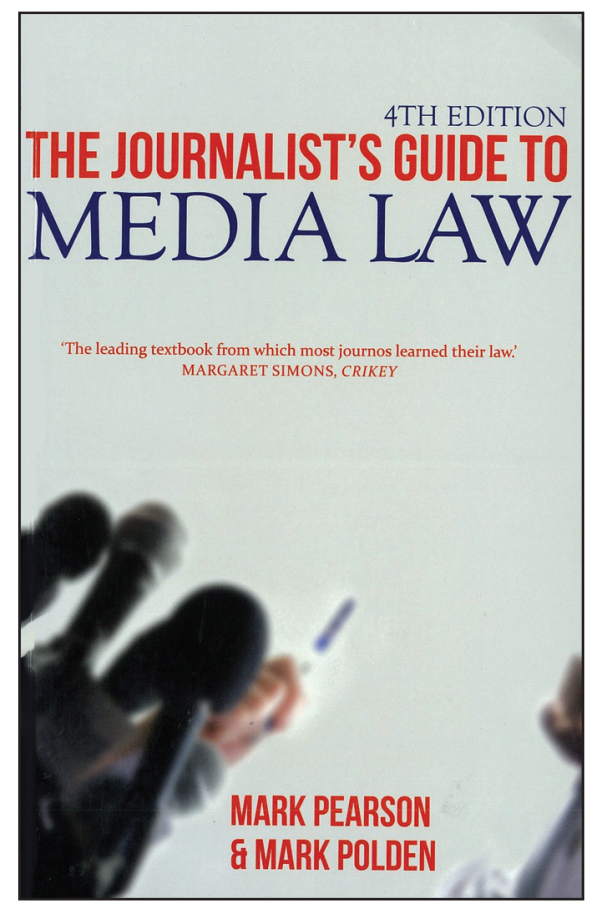

in Victoria that were apparently reported, somewhat controversially, on the front page of The Australian several hours before they had occurred. While, a third case was what Australian Twitter users dubbed the \#TwitDef saga, where The Australian's editor-in-chief Chris Mitchell claimed that he had been defamed by Australian journalism academic Julie Posetti, who had simply tweeted what a former News Corp journalist had said publically during the 2010 JEAA conference.

Fortunately, all three of these cases ended well, at least in the eyes 


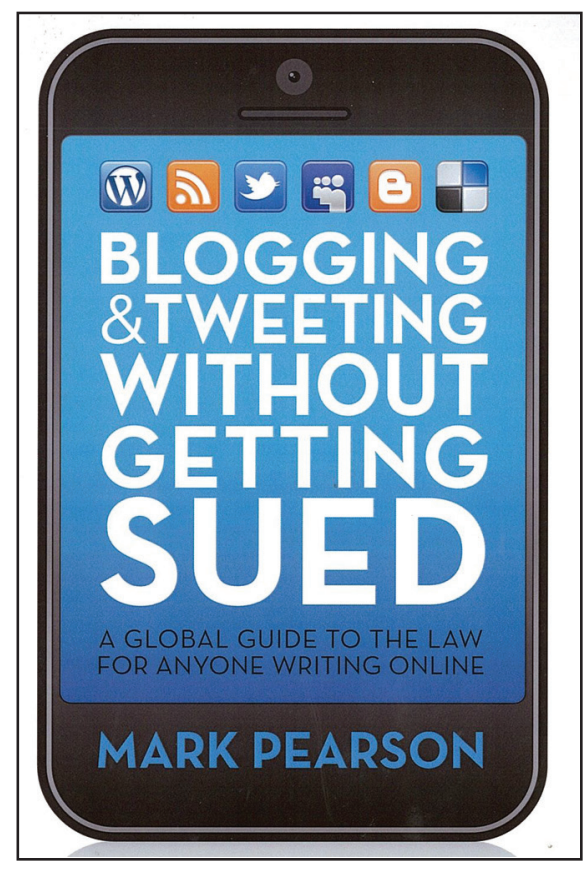

of anyone interested in the integrity of the fourth estate. The judge in the Rinehart case decided to uphold the 'shield' laws which can prevent journalists from having to reveal their sources, the police raids still went according to plan, and Chris Mitchell quickly backed down from his (rather puzzling) initial stance. However, each of these examples show us that the legal context of media practice remains very complicated. The internet, in particular, may be one of the best things ever invented as far as journalists trying to do their job are concerned, and it may well have propelled the forces of transparency quite considerably, but it has at the same time opened up a significant number of new challenges to those who wish to remain inside the law. And, perhaps most importantly, it has expanded almost exponentially the number of people to whom media law is relevant and important.

Fortunately, two bits of help are at hand.

The first is Mark Pearson and Mark Polden's The Journalists' Guide to Media Law. Now in its fourth edition (the first, though, with Polden's input as an experienced legal practitioner), this text does a fantastic job of covering the necessary ground in this space. Focussing on Australia, and Australian legal cases, the book provides a fantastic level of detail on all of the topics one would expect in a book like this: the legal system, legal principles, reporting on crime and the courts, defamation, confidentiality of sources, intellectual property and privacy, among many others. Whereas Butler and Rodrick's Australia Media Law (also now up to its fourth edition) represents a much more comprehensive guide to Australian Media Law in its entirety, this book provides exactly what it promises: a guide to the media law as it applies to journalists both current and hopeful.

Each chapter includes an overview of the topic, details of relevant, 
high-profile examples, and a very useful Q\&A section (covering the typical situations that practitioners are likely to encounter). For educators, there are also class discussion questions and useful websites. Written in a very accessible, straightforward manner, this book will deservedly remain the default textbook for the token law component of Journalism courses around Australia. It may be a little less useful in other national contexts, however, given the highly variable nature of the law from country-to-country.

The other bit of help comes from the same quarters, but tries to do something very different.

Pearson's Blogging and Tweeting Without Getting Sued is a shorter, cheaper, and more vernacular guide to the media law. Aimed squarely at (as the title suggests) non- or semiprofessionals, it will be an important read for anyone who has ambitions for being a professional writer online, but who hasn't necessarily studied their craft at a university at some point, or who doesn't have a lawyer's eyes overseeing their every move. Each chapter is short, punchy, and starts out with a (140 characters or less) 'Twitbrief' overview. The book is littered with interesting cases from around the world, and includes a long list of useful resources at the end, and key thinkers to follow on social media.
Of course, in providing such a global view, Pearson is simply unable to provide a clear set of guidelines to readers about how the law might apply to them. But, it does exactly the job it sets out to do, which is to make its readers-especially those who might otherwise be operating in a state of blissful ignorance - think more carefully about their day-to-day online communications, and be more aware of what might really be at stake. The internet might seem lawless, but it is anything but.

Each of these books serves a very different market, but both do an excellent job, and deserve to sell well, given media practitioners continue to navigate a dense legal minefield. 